\title{
ANALISIS KELAYAKAN FINANSIAL MESIN PEMANEN TEBU CANE HARVESTER (STUDI KASUS PADA PT LAJUPERDANA INDAH SITE KOMERING)
}

\author{
(Analysis of The Feasibility of Financially Cane Harvester Case Study at PT Lajuperdana Indah Site \\ Komering South Sumartra)
}

Rika Agustina, Dwi Haryono, Eka Kasymir

Jurusan Agribisnis, Fakultas Pertanian, Universitas Lampung, J1. Prof. Dr. Soemantri Brodjonegoro No. 1 Bandar Lampung, 35145,e-mail :dwi.haryono@fp.unila.ac.id

\begin{abstract}
This research aimed to analyses the productivity, thefinancial of feasibility and sensitivity of machine cane harvester. This research was a case study in PT Lajuperdana Indah Site Komering, South Sumatera. The data was collected in December 2016 andanalyzed by descriptive quantitative. The result of research suggested that big productivity machine cane harvester of 17.91 ton per hour work or 0.31 hectare per hour work or three hours of work to finish one hectare of land. The use of the machine cane harvester on PT Lajuperdana Indah Site Komering financially worth it to implement. The used of the machine cane harvester was sensitive at a change in the production of amounted to 19percent and increase in the17.58 percent but the value of payback period of the cane harvester was not sensitive.
\end{abstract}

Key words: cane harvester machine, financially analyse, productivity.

\section{PENDAHULUAN}

Sektor pertanian menjadi sektor yang memiliki peranan penting dalam membangun perekonomian negara. Hal tersebut dapat terjadi karena sektor pertanian mampu menjadi tumpuan hidup masyarakat. Menurut BPS (2016), terdapat beberapa sektor yang menjadi penyumbang terbesar bagi pendapatan negara. Salah satunya yaitu sektor pertanian. Besarnya kontribusi sektor pertanian pada pendapatan negara antara lain karena besarnya suplus neraca perdagangan subsektor perkebunan.

Badan Pusat Statistik (2015) menyebutkan bahwa luas perkebunan Indonesia memiliki potensi yang baik dalam beberapa komoditas pertanian seperti kelapa sawit, karet, tebu, teh, kopi, kina, tembakau, dan kakao yang mulai bergerak menguasai pasar dunia. Perkebunan tebu menjadi salah satu komoditas yang cukup luas dikembangkan di Indonesia. Perkebunan tebu merupakan perkebunan terluas ketiga yang diusahakan di Indonesia dan diharapkan mampu meningkatkan produksi gula sehingga mencapai swasembada gula. Bertambahnya luas perkebunan tebu di Indonesia dibarengi dengan kemajuan teknologi dibidang pertanian salah satunya pada bidang perkebunan tebu. Perkembangan mesin dan alat pertanian tebu diharapkan akan mampu membantu pekerjaan manusia dalam usahatani tebu.
Kebutuhan tenaga kerja saat ini pada bidang pertanian tidak dapat terpenuhi, karena banyak tenaga kerja yang mulai meninggalkan pekerjaan, khususnya pada bidang perkebunan. Pekerjaan dalam usahatani tebu tidak akan berjalan dengan baik dan sesuai dengan program rencana kegiatan jika kebutuhan tenaga kerja tidak terpenuhi. Terutama kekurangan tenaga kerja pada saat proses pemanenan akan mempengaruhi jumlah tebu yang dapat dikirim ke pabrik untuk di giling. Selain itu, keterlambatan proses pemanenan akan mempengaruhi kegiatan budidaya tebu selanjutnya.

Maka dari itu, untuk memenuhi kekurangan tenaga kerja maka perusahaan akan memanfaatkan mesin dan alat pertanian (Wahyudin 1995). Teknologi pertanian yang canggih akan meningkatkan produktivitas lahan. Manusia mulai mengembangkan mesin-mesin pertanian yang lebih canggih, maka secara perlahan namun pasti teknologi pertanian konvensional mulai ditinggalkan (Haryanti 2008). Penggunaan mesin pemanen tebu dapat dipertimbangkan untuk daerah yang memiliki keterbatasan tenaga kerja. Penggunaan mesin pemanen tebu dapat memberikan beberapa keuntungan antara lain dapat meningkatkan produktivitas sistem pemanenan, sehingga kegiatan pemanenan dapat memenuhi kapasitas giling pabrik. 
Penggunaan mesin pemanen tebu dapat menjadi solusi alternatif untuk mengatasi kekurangan tenaga kerja khususnya pada kegiatan pemanenan. Penggunaan mesin pemanen tebu memerlukan investasi yang cukup besar. Nilai investasi mesin pemanen tebu yang cukup mahal merupakan salah satu pertimbangan tersendiri bagi perusahaan. Besar nilai investasi untuk mesin pemanen tebu sekitar 5,6 hingga tujuh milyar rupiah per mesin pemanen tebu.

Salah satu perusahaan yang menggunakan mesin pemanen tebu untuk membantu kegiatan pemanenan adalah PT Lajuperdana Indah Site Komering. Penggunaan mesin pemanen tebu yang ada di PT Lajuperdana Indah Site Komering dinilai kurang optimum. Hal tersebut dapat dilihat pada keadaan lahan perkebunan yang belum memenuhi standar pemakaian mesin pemanen tebu tersebut. Keadaan tersebut dapat mengakibatkan biaya yang dikeluarkan tidak sebanding dengan hasil produksi yang diperoleh.

Peralihan sistem tebang manual menjadi sistem tebang mekanik bukanlah menjadi pilihan tetapi suatu keharusan bagi suatu perusahaan. Proses peralihan tersebut akan menyebabkan adanya perbedaan, baik pada produktivitas maupun biaya antar sistem tebang. Oleh karena itu, penelitian ini bertujuan untuk mengkaji pengalihan sistem panen manual menuju sistem panen mekanik pada produktivitas, kelayakan finansialserta sensitivitas kelayakan finansial penggunaan mesin pemanen tebu sebagai alih teknologi.

\section{METODE PENELITIAN}

Penelitian ini dilaksanakan di PT Lajuperdana Indah Site Komering Sumatera Selatan. Metode penelitian yang digunakan adalah metode studi kasus. Data yang dikumpulkan dalam penelitian ini adalah data primer yang diperoleh melalui wawancara langsung dengan responden dan data sekunder

Responden pada penelitian ini yaitu seorang manager harvesting, officer manual harvest, officer mechanical harvest, supervisor chopped caneserta staf administrasi harvesting. Responden tersebut dipilih dengan pertimbangan bahwa mereka memahami tentang mekanisme pemanenan yang ada di perusahaan.Penelitian dilaksanakan pada bulan Desember 2016.

Penelitian menggunakan analisis tabulasi yang diolah secara kantitatif. Metode tabulasi digunakan untuk mengetahui biaya pemanenan, produktivitas mesin pemanen tebu, analisis kelayakan finansial serta analisis sensitivitas mesin pemanen tebu. Analisis deskriptif digunakan untuk menjelaskan hasil yang diperoleh dari analisis kuantitatif.

Produktivitas mesin pemanen tebu dihitung berdasarkan produk (tebu) hasil panen pada masingmasing mesin pemanen tebu per satuan waktu pengerjaan panen (jam kerja) menggunakan rumus sebagai berikut:

Produktivitas $=\frac{\text { Produksi tebu }}{\text { Waktu kerja mesin }}$.

Biaya mesin pertanian terdiri dari biaya tetap dan biaya variabel. Biaya tetap biasa disebut juga dengan biaya kepemilikan, sedangkan biaya variabel atau biasa disebut dengan biaya operasional mesin pemanen tebu.

a. Unsur biaya yang termasuk dalam komponen biaya kepemilikan mesin pemanen tebu yaitu:

1. Biaya bunga modal

Biaya bunga modal dapat dihitung menggunakan rumus sebagai berikut (Pasaribu 2012):

$$
\mathrm{I}=\mathrm{i} \times \mathrm{P} .
$$

Keterangan:

I = Bunga modal

$\mathrm{i}=$ Tingkat suku bunga $(10,50 \%$ per tahun $)$

$\mathrm{P}=$ Harga pembelian mesin pemanen tebu

2. Beban gedung

Biaya gedung atau garasi dapat dihitung menggunakan rumus sebagai berikut (Ciptohadijoyo 1995):

$$
\text { Nilai Gedung }=\mathrm{h} \times \mathrm{P} \text {. }
$$

Keterangan:

$\mathrm{h}=$ Nilai gedung $(0.5 \%)$

$\mathrm{P}=$ Nilai investasi

b. Unsur yang termasuk pada biaya operasional atau biaya variabel mesin pemanen tebu meliputi: biaya bahan bakar yaitu pengeluaran solar pada kondisi kerja per jam mesin pemanen tebu, biaya perawatan preventif yang meliputi biaya perawatan mesin pemanen dan biaya minyak pelumas (oli mesin, oli gear box dan olihidrolik), biaya operator yang dihitung 
berdasarkan upah pada keadaan lokal. Biaya operator dihitung dengan sistem upah harian berdasarkan hari kerja.

c. Biaya Pokok (BP)

Biaya pokok merupakan biaya total tebang hingga angkut per ton tebu yang dihasilkan pada masing-masing sistem pemanenan yang dirumuskan sebagai berikut:

$$
\mathrm{BP}=\frac{\mathrm{BT}}{\mathrm{kx}}+\frac{\mathrm{BTT}}{\mathrm{k}} .
$$

Keterangan :

$$
\begin{aligned}
\mathrm{BP}= & \text { Biaya pokok }(\mathrm{Rp} / \text { unit produk) } \\
\mathrm{BT}= & \text { Biaya tetap }(\mathrm{Rp} / \mathrm{tahun}) \\
\mathrm{BT}= & \text { Biaya tidak tetap }(\mathrm{Rp} / \mathrm{jam} \text { atau } \mathrm{Rp} / \text { unit } \\
& \text { produk) } \\
\mathrm{x}= & \text { Perkiraan jam kerja (jam/tahun atau } \\
& \text { unit produk/jam) } \\
\mathrm{k}= & \text { Kapasitas mesin (unit produk/jam) }
\end{aligned}
$$

Analisis kelayakan finansial menjelaskan dan menilai suatu proyek dalam rangka memperoleh suatu tolok ukur yang mendasar dalam kelayakan investasi (Pasaribu 2012). Adapun kriteria tersebut adalah sebagai berikut:

a. Net Present Value (NPV)

NPV dihitung berdasarkan selisih antara benefit dengan biaya ditambah dengan investasi, yang dihitung melalu irumus (Pasaribu 2012).

$$
\mathrm{NPV}=\sum_{\mathrm{t}=\mathrm{n}}^{\mathrm{i}=0}(\mathrm{~B}-\mathrm{C})(\mathrm{df})
$$

Keterangan :

$\mathrm{Bt}=$ Manfaat (benefit) pada tahun ke-i

$\mathrm{Ct}=$ Biaya $(\cos t)$ pada tahun ke-i

$\mathrm{n} \quad=$ Umur $\operatorname{proyek}(8$ tahun $)$

$\mathrm{t} \quad=$ Tahun ke $1,2,3 \mathrm{dst}$

$\mathrm{i}=$ Discount rate $(10,75 \%)$

Indikator kelayakan NPV antara lain yaitu:

1. Jika NPV lebih dari 0, maka investasi layak dilaksanakan.

2. Jika NPV kurang dari 0, maka investasi tidak layak untuk dilaksanakan.

b. Net Benefit Cost Rasio (Net B/C)

Penilaian Net Benefit Cost Rasio (Net B/C) menunjukkan perbandingan antara jumlah penerimaan tunai terhadap biaya tunai. Perhitungan $\mathrm{Net} B / C$ rasio:

$$
\operatorname{Net} \frac{\mathrm{B}}{\mathrm{C}}=\frac{\sum_{\mathrm{t}=0}^{\mathrm{n}} \mathrm{Bt}-\mathrm{Ct} /(1+\mathrm{i})^{\mathrm{t}}}{\sum_{\mathrm{t}=0}^{\mathrm{n}} \mathrm{Ct}-\mathrm{Bt} /(1+\mathrm{i})^{\mathrm{t}}}
$$

Keterangan :

$\mathrm{Bt}=$ Manfaat (benefit) pada tahun ke-i

$\mathrm{Ct}=$ Biaya (cost) pada tahun ke-i

$\mathrm{n}=$ Umur proyek(8 tahun)

$\mathrm{t} \quad=$ Tahun ke $1,2,3 \mathrm{dst}$

$\mathrm{i}=$ Discount rate $(10,50 \%)$

Indikator kelayakan Net Benefit Cost Rasio (Net B/C) yaitu:

1. Jika Net Benefit Cost Rasio (Net B/C) lebih dari 1 maka proyek layak dilaksanakan,

2. Jika Net Benefit Cost Rasio (Net B/C) kurang dari 1 maka proyek tersebut tidak layak untuk dilaksanakan.

c. Gross Benefit Cost Rasio (Gross B/C)

Analisis benefit cost yaitu rasio antara manfaat bersih yang bernilai positif dengan manfaat bersih yang bersifat negatif. Penerapan analisis $\mathrm{B} / \mathrm{C}$ rasio diperlukan untuk melihat sejauhmana perbandingan antara nilai manfaat terhadap biaya.

Persamaan B/C Rasio yaitu:

$$
\operatorname{Gross} \frac{\mathrm{B}}{\mathrm{C}}=\frac{\sum \mathrm{Bt} /(1+\mathrm{i})^{\mathrm{t}}}{\sum \mathrm{Ct} /(1+\mathrm{i})^{\mathrm{t}}}
$$

Keterangan :

$\mathrm{Bt}=$ Manfaat (benefit) pada tahun ke-i

$\mathrm{Ct}$ = Biaya (cost) pada tahun ke-i

$\mathrm{i}=$ Suku bunga $(10,50 \%)$

$\mathrm{t} \quad=$ Tahun ke $1,2,3 \mathrm{dst}$

Indikator kelayakan Gross Benefit Cost Rasio (Gross B/C) yaitu:

1. Jika Gross Benefit Cost Rasio (Gross B/C) lebih dari 1, maka proyek layak dilaksanakan

2. Jika Gross Benefit Cost Rasio (Gross B/C) kurang dari 1, maka proyek tersebut tidak layak untuk dilaksanakan.

d. Internal Rate of Return (IRR)

Internal Rate of Return (IRR) digunakan untuk mengetahui dan sebagai alat ukur kemampuan proyek dalam pengembalian bunga pinjaman dari lembaga internal keuangan yang membiayai proyek tersebut dari lembaga internal keuangan yang membiayai proyek tersebut. Perhitungan Internal Rate of Return (IRR) yaitu:

$$
\mathrm{IRR}=\mathrm{i} 1+\left\{\frac{\mathrm{NPV} 1}{\mathrm{NPV} 1-\mathrm{NPV} 2}\right\}(\mathrm{i} 1-\mathrm{i} 2) \ldots
$$


Keterangan:

NPV $1=$ Net present value percobaan

NPV 2 = Net present value percobaan kedua

i' $\quad=$ Discount factor percobaan pertama

i” $\quad=$ Discount factor percobaan kedua

Indikator kelayakan Internal Rate of Return (IRR) yaitu:

1. Jika Internal Rate of Return (IRR) lebih dari tingkat suku bunga yang berlaku, maka proyek akan memberikan keuntungan jika dilaksanakan.

2. Jika Internal Rate of Return (IRR) kurang dari tingkat suku bunga yang berlaku, maka proyek tersebut tidak memberikan keuntungan tapi menyebabkan kerugian untuk dilaksanakan.

\section{e. Payback Periode (PP)}

Payback Periode (PP) merupakan jangka waktu pengembalian modal investasi yang akan dibayarkan melalui keuntungan yang diperoleh proyek tersebut.

Perhitungan Payback Periode (PP) yaitu:

$$
\mathrm{PP}=\frac{\text { Jumlah investasi }}{\text { Net benefit tiap tahun }}
$$

Indikator kelayakan Payback Periode (PP) yaitu:

1. Jika Payback Period lebih pendek dari umur ekonomis usaha, maka proyek tersebut layak untuk dijalankan.

2. Jika Payback Period lebih lama dari umur ekonomis usaha, maka proyek tersebut tidak layak untuk dijalankan.

Analisis sensitivitas akan memberikan gambaran sejauhmana suatu keputusan akan konsisten meskipun terjadi perubahan pada faktor-faktor atau parameter yang mempengaruhinya (Gittinger 2008). Pada analisis kepekaan terdapat beberapa kemungkinan yang harus dicoba. Hal ini perlu, karena analisis proyek biasanya didasarkan pada proyeksi-proyeksi yang mengandung banyak ketidakpastian dan perubahan yang akan terjadi pada masa yang akan datang (Astanu 2013). Secara matematis, laju kepekaan dapat dirumus sebagai berikut:

$$
\text { Laju kepekaan }=\frac{\left|\frac{\mathrm{Xi}-\mathrm{Xo}}{\mathrm{X}}\right| \times 100 \%}{\left|\frac{\mathrm{Yi}-\mathrm{Yo}_{0}}{\mathrm{Y}}\right| \times 100 \%}
$$

Keterangan :

$$
\begin{aligned}
& \mathrm{Xi}= \text { Gross } \mathrm{B} / \mathrm{C} / \text { Net } \mathrm{B} / \mathrm{C} / \mathrm{NPV} / \mathrm{IRR} / \mathrm{PP} \text { setelah } \\
& \text { perubahan } \\
& \mathrm{Xo}= \begin{array}{l}
\text { Gross } \mathrm{B} / \mathrm{C} / \text { Net } \\
\text { sebelum perubahan }
\end{array} \\
& \mathrm{X} / \mathrm{C} / \mathrm{NPV} / \mathrm{IRR} / \mathrm{PP} \\
& \mathrm{X}= \text { Rata-rata perubahan Gross } \mathrm{B} / \mathrm{C} / \text { Net } \mathrm{B} / \mathrm{C} / \\
& \mathrm{NPV} / \mathrm{IRR} / \mathrm{PP} \\
& \mathrm{Yi}= \begin{array}{l}
\text { Biaya produksi/harga jual setelah } \\
\text { perubahan }
\end{array} \\
& \mathrm{Yo}=\begin{array}{l}
\text { Biaya produksi/harga jual sebelum } \\
\text { perubahan }
\end{array} \\
& \mathrm{Y}=\begin{array}{l}
\text { Rata-rata perubahan biaya produksi } / \\
\text { harga jual. }
\end{array}
\end{aligned}
$$

Kriteria laju kepekaan:

1. Jika laju kepekaan lebih dari satu, maka usaha sensitif terhadap perubahan.

2. Jika laju kepekaan kurang dari satu, maka usaha tidak sensitif terhadap perubahan.

Perubahan-perubahan yang digunakan pada analisis sensitivitas mesin pemanen tebu antara lain yaitu terjadi penurunan jumlah produksi tebu sebesar 19 persen, perubahan jumlah produksi sebesar 19 persen berdasarkan perubahan maksimal rata-rata dari jumlah produksi masingmasing mesin pemanen tebu yang pernah terjadi, serta terjadi kenaikan biaya sebesar 17,58 persen dengan asumsi apabila terjadi kenaikan nilai inflasi sebesar dua kali nilai inflasi tertinggi yang terjadi pada bulan Agustus tahun 2013. Aspek tersebut sama dengan seperti yang dilakukan Sari (2016).

\section{HASIL DAN PEMBAHASAN}

\section{Pemanenan Tebu}

Pemanenan tebu merupakan suatu proses pengambilan hasil produksi dari kegiatan budidaya tebu. Kegiatan pemanenan yang ada di PT Lajuperdana Indah Site Kemering menjadi tanggung jawab divisi harvesting. Sistem pemanenan yang saat ini dilaksanakan oleh PT Lajuperdana Indah Site Komering yaitu sistem pemanenan secara mekanik (chopped cane) dan manual (bundled cane).

Metode pemanenan tebu yang dilaksanakan oleh PT Lajuperdana Indah Site Komering adalah metode tebu hijau, yaitu pemanenan tebu dengan tidak memberikan perlakuan sebelum pemanenan, seperti pembakaran tebu sebelum dipanen. Tebu yang dipanen dalam kondisi masih segar 
Teknik pemanenan tebu pada PT Lajuperdana Indah Site Komering yaitu:

\section{Bundled cane atau tebu ikat}

Bundled cane atau tebu ikat yaitu teknik pemanenan tebu secara manual dengan memanfaatkan tenaga kerja manusia. Hasil pemanenan tebu dengan teknik bundled cane yaitu tebu dalam bentuk lonjoran atau batang tebu utuh.

2. Chopped cane atau tebu cacah

Chopped cane merupakan teknik pemanenan tebu dengan memanfaatkan mesin pemanen tebu yang akan menghasilkan tebu hasil panen dalam bentuk cacahan atau potongan dengan panjang 20-30 cm. Kegiatan pemanenan dengan secara mekanik menggunakan mesin pemanen tebu (cane harvester). Mesin pemanen tebu yang ada di PT Lajuperdana Indah Site Komering sebanyak 11 unit. Mesin pemanen tebu dibeli secara bertahap. Mesin pemanen tebu sebanyak dua unit dibeli pada tahun 2012, 2 unit pada tahun 2013, empat unit pada tahun 2015 dan tiga unit pada tahun 2016.

\section{Produktivitas Mesin Pemanen Tebu}

Besar nilai produktivitas rata-rata mesin pemanen tebu yaitu berkisar antara 0,29 hingga 0,32 hektar per jam kerja. Hal tersebut dapat terjadi disebabkan oleh beberapa faktor, diantaranya yaitu kemiringan lahan di PT Lajuperdana Indah Site Komering lebih dari 17 derajad, pola petak kebun yang masih banyak dikelilingi lebung dan panjang guludan tiap petak yang masih pendek-pendek. Produktivitas mesin pemanen tebu dapat mencapai nilai produktivitas yang tinggi jika kondisi lahan yang sesuai dengan kondisi standar pengoperasian mesin pemanen tebu.

Berdasarkan Tabel 1,rata-rata produktivitas mesin pemanen tebu tahun investasi 2012 sebesar 17,32 ton per jam kerja atau 0,29 hektar per jam kerja, mesin pemanen tebu tahun investasi 2013 sebesar 17,69 ton per jam kerja atau 0,29 hektar per jam kerja dan mesin pemanen tebu tahun investasi 2015 sebesar 18,32 ton per jam kerja atau 0,32 hektar per jam kerja. Rata-rata produktivitas mesin pemanen tebu tahun investasi 2015 lebih tinggi dibandingkan dengan mesin pemanen tebu tahun investasi 2012 dan 2013 yang dihitung berdasarkan jumlah tonase tebu yang dapat dipanen dan jumlah luas lahan yang dapat dipanen per jam kerja mesin. Hal ini dapat disebabkan kemampuan daya kerja mesin serta umur pakai mesin pemanen tebu tahun investasi 2015 yang semakin tinggi dibandingkan dengan daya kerja mesin tahun investasi 2012 dan 2013.

\section{Analisis Kelayakan Finansial Mesin Pemanen Tebu}

Analisis mesin pemanen tebu dilakukan pada delapan mesin pemanen tebu yaitu mesin pemanen tebu $\mathrm{CH} 01, \mathrm{CH} 02, \mathrm{CH} 03, \mathrm{CH} 04, \mathrm{CH} 05, \mathrm{CH} \mathrm{06,}$ $\mathrm{CH} 07$ dan $\mathrm{CH}$ 08. Analisis finansial mesin pemanen tebu (cane havester) dipengaruhi oleh besar biaya dan penerimaan mesin pemanen tebu. Biaya mesin pemanen tebu (cane havester) antara lain yaitu:

\section{Biaya Mesin Pemanen Tebu}

Biaya tersebut terdiri dari biaya tetap dan biaya operasional. Biaya tetap penggunaan mesin pemanen tebu terdiri dari biaya investasi mesin pemanen tebu, biaya garasi dan biaya pajak.Biaya operasional mesin pemanen tebu terdiri biaya servis, biaya pelumas, biaya bahan bakar dan biaya tenaga kerja. Biaya servis mesin pemanen tebu meliputi biaya servis spare parts, baterai, tyre, dan filter.

Tabel 1. Produktivitas mesin pemanen tebu berdasarkan tahun investasi

\begin{tabular}{|c|c|c|c|c|c|c|c|c|}
\hline \multirow[t]{2}{*}{ No. } & \multicolumn{2}{|c|}{$\begin{array}{l}\text { Produktivitas Mesin } \\
\text { Pemanen Tebu } 2012 \\
\end{array}$} & \multirow[t]{2}{*}{ No. } & \multicolumn{2}{|c|}{$\begin{array}{l}\text { Produktivitas Mesin } \\
\text { Pemanen Tebu } 2013\end{array}$} & \multirow[t]{2}{*}{ No. } & \multicolumn{2}{|c|}{$\begin{array}{l}\text { Produktivitas Mesin } \\
\text { Pemanen Tebu } 2015\end{array}$} \\
\hline & Ton/ HM & $\mathrm{Ha} / \mathrm{HM}$ & & Ton/ HM & $\mathrm{Ha} / \mathrm{HM}$ & & Ton/ HM & $\mathrm{Ha} / \mathrm{HM}$ \\
\hline $\mathrm{CH} 01$ & 18,12 & 0,30 & $\mathrm{CH} 03$ & 17,75 & 0,29 & $\mathrm{CH} 05$ & 16,58 & 0,29 \\
\hline \multirow[t]{3}{*}{$\mathrm{CH} 02$} & 16,52 & 0,28 & $\mathrm{CH} 04$ & 17,63 & 0,29 & CH06 & 17,97 & 0,32 \\
\hline & & & & & & CH07 & 18,77 & 0,33 \\
\hline & & & & & & CH08 & 19,96 & 0,36 \\
\hline Total & 34,65 & 0,58 & Total & 35,38 & 0,58 & Total & 73,28 & 1,30 \\
\hline Rata-rata & 17,32 & 0,29 & Rata-rata & 17,69 & 0,29 & Rata-rata & 18,32 & 0,32 \\
\hline
\end{tabular}


Pelumas atau oli yang digunakan pada mesin pemanen tebu terdiri dari oli hidrolik, oli mesin dan oli gear box atau gardan. Jumlah oli yang dibutuhkan untuk satu kali servis rutin yaitu 405 liter oli hidrolik, 30 liter oli mesin dan 40 liter oli gear box.

Mesin pemanen tebu membutuhkan bahan bakar (solar) sebanyak 33 liter/jam kerja dan membutuhkan dua tenaga kerja pada setiap mesin pemanen tebu yang terdiri dari seorang operator dan mekanik. Operator dan mekanik memiliki jam kerja 24 jam yang dibagi ke dalam tigashift. Ratarata dalam satu tahun musim panen tebu selama 136 hari. Besar biaya total masing-masing mesin pemanen tebu dapat dilihat pada Tabel 2 .

Tabel 2 menunjukkan besar biaya pokok dari masing-masing mesin pemanan tebu pada PT Lajuperdana Indah Site Komering. Besar biaya yang dikeluarkan yaitu sebesar Rp64.661,00 per ton tebu, sedangkan besar biaya pemanenan secara manual membutuhkan biaya sebesar Rp97.000,00 per ton tebu yang terdiri dari biaya tebang dan muat batang tebu ke armada pengangkut. Besar biaya dengan menggunakan mesin pemanen tebu lebih rendah jika dibandingkan dengan biaya pemanenan pada sistem manual. Hal ini tidak sejalan dengan hasil penelitian Haryanti (2008) tentang analisa sistem pemanenan tebu (Saccharum officinarum L.) yang optimal di PG Jatitujuh, Majalengka, Jawa Barat yang menyatakan bahwa biaya pemanenan dengan sistem panen manual lebih rendah bila dibandingkan dengan besar biaya pemanenan dengan sistem mekanik (mesin pemanen tebu). Besar biaya pemanenan pada sistem tebang manual yaitu sebesar Rp53.290,00 per ton tebu, sedangkan pada sistem tebang mekanik sebesar Rp55.680,00 per ton tebu.

\section{Produksi}

Rata-rata besar produksi tebu yang dapat dipanen dengan mesin pemanen tebu yaitu 32.780 ton tebu per mesin pemanen tebu per musim panen. Besar rendementebu pada PT Lajuperdana IndahSite Komering yaitu sebesar 6,83. Rendemen tebu pada PT Lajuperdana Indah mengalami penurunan daritahun sebelumnya. Hal terebut dapat terjadi karena peralihan metode panen tebu dari tebu bakar menjadi tebu hijau. Rendemen tebu hijau lebih rendah dibandingkan dengan tebu bakar.

Output yang dihasilkan oleh mesin pemanen tebu adalah jumlah tebu yang mampu dipanen dengan mesin pemanen tebu, sehingga besar nilai penerimaan dari mesin pemanen tebu dihitung berdasarkan ton tebu yang dapat dihasilkan dikalikan dengan besar biaya panen tebu per ton secara manual. Besar penerimaan mesin pemanen tebu merupakan biaya yang dapat dihemat oleh perusahaan dengan adanya alih teknologi pada sisem pemanen tebu. Jika jumlah rata-rata tebu yang mampu dipanen oleh mesin pemanen tebu yaitu sebesar 32.780 ton tebu dengan harga upah panen tebu secara manual sebesar Rp97.000,00 per ton, maka rata-rata penerimaan masing-masing mesin pemanen tebu yaitu sebesar Rp3.179.660.000,00 per musim panen.

Tabel 2. Besar biaya total mesin pemanen tebu 2016

\begin{tabular}{cccc}
\hline Unit Mesin & $\begin{array}{c}\text { Rata-Rata Biaya/Musim } \\
(\mathrm{Rp})\end{array}$ & $\begin{array}{c}\text { Rata-Rata Produksi/Musim } \\
(\text { Ton })\end{array}$ & $\begin{array}{c}\text { Biaya Pemanenan Tebu } \\
(\mathrm{Rp} / \text { Ton })\end{array}$ \\
\hline CH 01 & 1.714 .663 .943 & 17.210 & 99.632 \\
CH 02 & 1.989 .268 .169 & 26.221 & 75.865 \\
CH 03 & 1.866 .254 .813 & 24.406 & 76.468 \\
CH 04 & 1.796 .066 .495 & 23.858 & 75.281 \\
CH 05 & 2.085 .521 .473 & 60.054 & 34.727 \\
CH 06 & 1.912 .218 .699 & 25.390 & 75.314 \\
CH 07 & 1.771 .257 .262 & 50.210 & 35.277 \\
CH 08 & 1.560 .420 .798 & 34.891 & 44.723 \\
\hline \multicolumn{2}{l}{ Total biaya pokok per ton tebu } & 262.240 & 517.286 \\
\hline Rata-rata biaya pokok per ton tebu & 32.780 & 64.661 \\
\hline
\end{tabular}

Keterangan: $\mathrm{CH}=$ Cane Harvester 
Tabel 3. Hasil analisis finansial mesin pemanen tebu (cane harvester) pada PT Lajuperdana Indah Site Komering

\begin{tabular}{crrccc}
\hline \multirow{2}{*}{ Unit } & \multicolumn{5}{c}{ Kriteria Investasi } \\
& NPV & IRR (\%) & Gross B/C & Net B/C & PP \\
\hline CH 01 & -1.566 .984 .464 & 1,72 & 1,02 & 0,78 & 2,88 \\
CH 02 & 2.815 .808 .410 & 22,00 & 1,32 & 1,38 & 2,67 \\
CH 03 & 4.029 .239 .623 & 32,49 & 1,31 & 1,79 & 1,91 \\
CH 04 & 3.106 .097 .216 & 30,27 & 1,33 & 1,55 & 2,16 \\
CH 05 & 18.618 .513 .283 & 57,05 & 2,83 & 3,92 & 2,88 \\
CH 06 & 2.074 .036 .060 & 21,67 & 1,33 & 1,36 & 3,04 \\
CH 07 & 15.860 .113 .409 & 63,35 & 2,80 & 3,93 & 2,42 \\
CH 08 & 8.061 .641 .424 & 35,19 & 2,22 & 2,26 & 3,44 \\
\hline
\end{tabular}

\section{Analisis Kriteria Investasi}

Analisis kelayakan finansial digunakan untuk menilai kemampuan investasi mesin pemanen tebu dalam menghasilkan keuntungan bagi perusahaan atas biaya investasi yang telah dikeluarkan. Kriteria analisis investasi yang digunakan antara lain yaitu Gross B/C, Net B/C, NPV, IRR, dan PP. Tingkat suku bunga yang digunakan dalam perhitungan yaitu 10,50 persen (Bank Indonesia 2016), tingkat suku bunga yang digunakan merupakan tingkat suku bunga pinjaman korporasi pada Bank Rakyat Indonesia. Kriteria lain yang digunakan pada analisis ini ialah penggunaan compounding factor dan discount factor secara kombinasi. Kombinasi ini digunakan agar hasil perhitungan tidak hanya mengevaluasi proyek investasi tetapi juga melihat prospek investasi ke depan (Pratiwi 2016). Setelah dilakukan perhitungan terhadapinvestasi mesin pemanen tebu (cane harvester) maka diperoleh hasil sebagai berikut yang disajikan pada Tabel 3 .

Tabel 3, menunjukkan hasil perhitungan analisis kelayakan finansial mesin pemanen tebu dengan kriteria Net Present Value (NPV), IRR, Net B/C, Gross $B / C$ dan Payback Periode. Nilai dari kriteria kelayakan finansial penggunaan mesin pemanen tebu sebagai alih teknologi pada kegiatan pemanen tebu layak untuk dilaksanakan. Walaupun perusahaan diharuskan menginvestasikan sebagian pendapatannya untuk melakukan pengadaan investasi mesin pemanen tebu yang cukup mahal akan tetapi pengeluaran tersebut nilainya tidak sebanding dengan keuntungan yang nantinya akan didapatkan oleh perusahaan.

\section{Analisis Sensitivitas}

Berdasarkan Tabel 4, hasil analisis sensitivitas pada delapan mesin pemanen tebu yang ada di PT
Lajuperdana Indah Site Komering maka diketahui Berdasarkan Tabel 4, hasil analisis sensitivitas pada delapan mesin pemanen tebu yang ada di PT Lajuperdana Indah Site Komering maka diketahui bahwa nilai NPV, IRR, dan Net $B / C$ mesin pemanen tebu sensitif terhadap perubahan produksi sebesar 19 persen, tetapi tidak sesitif pada kenaikan biaya akibat inflasi sebesar 17,58 persen, sedangkan nilai Gross B/C dan Payback periode tidak sensitif terhadap perubahan produksi dan kenaikan biaya sebesar 17,58 persen. Penurunan produksi sebesar 19,00 persen dapat mempengaruhi penilaian investasi mesin pemanen tebu. Hal tersebut dapat di lihat berdasarkan nilai laju kepekaan untuk NPV, IRR dan Net B/C yang lebih dari satu dan nilai laju kepekaan untuk Gross B/C dan Payback periode yang kurang dari satu. Perubahan biaya produksi tidak mempengaruhi penilaian kelayakan investasi mesi pemanen tebu yan ditunjukkan oleh nilai laju kepekaan mesin pemanen tebu yang kurang dari satu pada skenario perubahan biaya produksi sebesar 17,58 persen.

\section{KESIMPULAN}

Produktivitas mesin pemanen tebu (cane harvester) berkisar antara 0,29 hingga 0,32 hektar per jam kerja atau dapat menyelesaikan satu hektar luas panen dalam waktu tiga jam kerja, dengan produktivitas mesin pemanen tebu 17,32 hingga 18,32 ton per jam. Satu mesin pemanen tebu dapat menggantikan 147 orang tenaga kerja manusia jika dikerjakan dalam waktu yang sama (satu jam kerja). Secara finansial penggunaan mesin pemanen tebu pada PT Lajuperdana Indah Site Komering layak untuk dilaksanakan. Penggunaan mesin pemanen tebu tetap layak dilaksanakan pada saat terjadi perubahan penurunan produksi sebesar 19,00 persen, kenaikan biaya sebesar 17,58 persen. 
JIIA, VOLUME 8 No. 1, FEBRUARI 2020

Tabel 4. Analisis sensitivitas kelayakan finansial mesin pemanen tebu (Cane Harvester)

\begin{tabular}{|c|c|c|c|c|c|c|c|c|c|c|}
\hline \multirow{3}{*}{ Mesin ke } & \multicolumn{10}{|c|}{ Skenario } \\
\hline & \multicolumn{5}{|c|}{ Penurunan Produksi 19,00\% } & \multicolumn{5}{|c|}{ Kenaikan Biaya $17,58 \%$} \\
\hline & NPV & IRR & Gross B/C & Net B/C & PP & NPV & IRR & Gross B/C & Net B/C & PP \\
\hline $\mathrm{CH} 01$ & TS & TS & TS & $\mathrm{S}$ & TS & $\mathrm{S}$ & $\mathrm{S}$ & TS & TS & TS \\
\hline $\mathrm{CH} 02$ & $\mathrm{~S}$ & $\mathrm{~S}$ & $\mathrm{~S}$ & $\mathrm{~S}$ & $\mathrm{TS}$ & TS & TS & $\mathrm{TS}$ & $\mathrm{TS}$ & TS \\
\hline $\mathrm{CH} 03$ & $\mathrm{~S}$ & $\mathrm{~S}$ & TS & $\mathrm{S}$ & TS & TS & TS & TS & $\mathrm{TS}$ & TS \\
\hline $\mathrm{CH} 04$ & $\mathrm{~S}$ & $\mathrm{~S}$ & TS & $\mathrm{S}$ & TS & TS & TS & $\mathrm{TS}$ & TS & TS \\
\hline $\mathrm{CH} 05$ & $\mathrm{~S}$ & $\mathrm{~S}$ & TS & $\mathrm{S}$ & TS & TS & TS & TS & $\mathrm{TS}$ & TS \\
\hline CH 06 & TS & $\mathrm{S}$ & TS & $\mathrm{S}$ & TS & TS & TS & TS & TS & TS \\
\hline CH 07 & $\mathrm{~S}$ & TS & $\mathrm{S}$ & TS & TS & TS & $\mathrm{TS}$ & TS & TS & TS \\
\hline CH 08 & $\mathrm{~S}$ & $\mathrm{~S}$ & $\mathrm{~S}$ & TS & TS & TS & TS & TS & TS & TS \\
\hline
\end{tabular}

Keterangan :

TS = Nilai laju kepekaan kurang dari atau sama dengan 1

$\mathrm{S}=$ Nilai laju pekekaan lebih dari 1

\section{DAFTAR PUSTAKA}

Astanu DA, Ismono RH, Rosanti N. 2013. Analisis kelayakan finansial budidaya intensif tanaman pala di Kecamatan Gisting Kabupaten Tanggamus. JIIA, 1(3): 218-225. http://jurnal.fp.unila.ac.id/index.php/JIIA/art icle/view/567/538. [6 April 2017].

BPS [Badan Pusat Statistik]. 2015. Luas Lahan dan Produksi Perkebunan Tebu Tahun 2014. Badan Pusat Statistik. Jakarta. 2016. Distribusi PDB Triwulan Atas Dasar Harga Berlaku Menurut Lapangan Usaha (Persen) 20142016. Badan Pusat Statistik. Jakarta.

BI [Bank Indonesia]. 2016. Suku Bunga Dasar Kredit.http://www.bi.go.id/id/perbankan/suk u-bunga-dasar. [27 Desember 2016]

Ciptohadidjiyo S. 1996. Perencanaan Pengembangan Alat dan Mesin Pertanian. Tim Pengawas Pengelolaan SKR. Palangka Raya.

Gittinger JP dan Adler AH. 2008. Analisis Ekonomi Proyek-Proyek Pertanian. Cetakan Ketiga. PT Rineka Cipta. Jakarta.
Haryanti V. 2008. Analisa sistem pemanen tebu (Saccarum officinarum) yang optimal di PG. Jatitujuh Majalengka Jawa Barat. Skripsi. Institut Pertanian Bogor. Bogor

Pasaribu AM. 2012. Perencanaan dan Evaluasi Proyek. Lily PublicSher. Jakarta.

Pramudya B. 1999. Permodelan sistem pada perencanaan mekanisasi dalan kegiatan pemanenan tebu. Disertasi. Institut Pertanian Bogor. Bogor.

Pratiwi D, Hasyim AI, dan Affandi MI. 2016. Analisis finansial dan strategi pengembangan nanas madu di Kabupaten Lampung Timur. JIIA, 4(1): 8-14. http://jurnal.fp.unila.ac.id/index.php/JIA/arti cle/view/1209/1106. [6 April 2017].

Sari DI, Affandi MI, dan Soelaiman. 2016. Finansial usaha pengolahan bahan olah karet (Bokar) di Kabuaten Tulang Bawang Barat. JIIA, 4(2):118-125. http://jurnal.fp.unila.ac. id/index.php/JIA/article/view/1228/1125.[6 April 2017].

Wahyudin. 1995. Analisis kebutuhan tenaga kerja dan biaya pemanenan tebu di PG. Madismo Yogyakarta. Skripsi. Institut Pertanian Bogor. Bogor. 